\title{
De meting van de werkloosheid onder schoolverlaters : een vergelijking van CBS- en ROA-cijfers
}

Citation for published version (APA):

van der Velden, R. K. W., Willems, E., \& Welters, R. A. M. H. M. (1998). De meting van de werkloosheid onder schoolverlaters : een vergelijking van CBS- en ROA-cijfers. Researchcentrum voor Onderwijs en Arbeidsmarkt, Faculteit der Economische Wetenschappen. ROA Working Papers No. 3 https://doi.org/10.26481/umarow.1998003

Document status and date:

Published: 01/01/1998

DOI:

10.26481/umarow.1998003

Document Version:

Publisher's PDF, also known as Version of record

\section{Please check the document version of this publication:}

- A submitted manuscript is the version of the article upon submission and before peer-review. There can be important differences between the submitted version and the official published version of record.

People interested in the research are advised to contact the author for the final version of the publication, or visit the DOI to the publisher's website.

- The final author version and the galley proof are versions of the publication after peer review.

- The final published version features the final layout of the paper including the volume, issue and page numbers.

Link to publication

\footnotetext{
General rights rights.

- You may freely distribute the URL identifying the publication in the public portal. please follow below link for the End User Agreement:

www.umlib.nl/taverne-license

Take down policy

If you believe that this document breaches copyright please contact us at:

repository@maastrichtuniversity.nl

providing details and we will investigate your claim.
}

Copyright and moral rights for the publications made accessible in the public portal are retained by the authors and/or other copyright owners and it is a condition of accessing publications that users recognise and abide by the legal requirements associated with these

- Users may download and print one copy of any publication from the public portal for the purpose of private study or research.

- You may not further distribute the material or use it for any profit-making activity or commercial gain

If the publication is distributed under the terms of Article $25 \mathrm{fa}$ of the Dutch Copyright Act, indicated by the "Taverne" license above, 
De meting van de werkloosheid onder schoolverlaters Een vergelijking van CBS- en ROA-cijfers

ROA-W-1998/3

Rolf van der Velden, Riccardo Welters, Ed Willems

Researchcentrum voor Onderwijs en Arbeidsmarkt

Faculteit der Economische Wetenschappen en Bedrijfskunde Universiteit Maastricht

Maastricht, september 1998 
ISBN 90-5321-235-3

SEC98.157/EW 
Inhoud

Bladzijde

Voorwoord

1 Inleiding 1

2 Verschillen in enquête-opzet 3

3 Analyse van de verschillen $\quad 6$

4 Conclusie 10

$\begin{array}{ll}\text { Literatuur } & 11\end{array}$ 


\section{Voorwoord}

Het Centraal Bureau voor de Statistiek (CBS) en het Researchcentrum voor Onderwijs en Arbeidsmarkt (ROA) publiceren jaarlijks, onafhankelijk van elkaar, gegevens over de werkloosheid onder schoolverlaters. Door verschillen in databronnen en methoden lopen de werkloosheidspercentages die door beide instituten worden gepresenteerd nogal uiteen. Dit werkdocument geeft inzicht in de oorzaken van de verschillen in het werkloosheidspercentage. Het werkdocument is samengesteld door het ROA in nauwe samenwerking met het CBS. De eindverantwoordelijkheid ligt bij het ROA. Het onderzoek is uitgevoerd drs. R.A.M.H.M. Welters, onder leiding van dr. R.K.W. van der Velden en drs. E.J.T.A. Willems. Vanuit het CBS is het project begeleid door ing. A.M.W. Reemers en drs. J. van der Valk. 


\section{Inleiding}

Zowel het Researchcentrum voor Onderwijs en Arbeidsmarkt (ROA) als het Centraal Bureau voor de Statistiek (CBS) publiceren jaarlijks gegevens over de arbeidsmarktsituatie van schoolverlaters ${ }^{1}$. Een belangrijke maatstaf die daarbij wordt gehanteerd is het werkloosheidspercentage. Opmerkelijk is dat de gepresenteerde werkloosheidspercentages van het ROA beduidend lager liggen dan die van het CBS. Beide cijfers worden ongeveer gelijktijdig gepubliceerd. Hierdoor ontstaat verwarring over de 'juistheid' van de cijfers. Voor de transparantie van de aansluiting onderwijs-arbeidsmarkt is dit - zowel voor studenten als beleidsmakers - ongewenst. Daarom hebben ROA en CBS gezamenlijk besloten het verschil in resultaten te onderzoeken.

\section{Figuur 1}

Onderzoeksaanpak

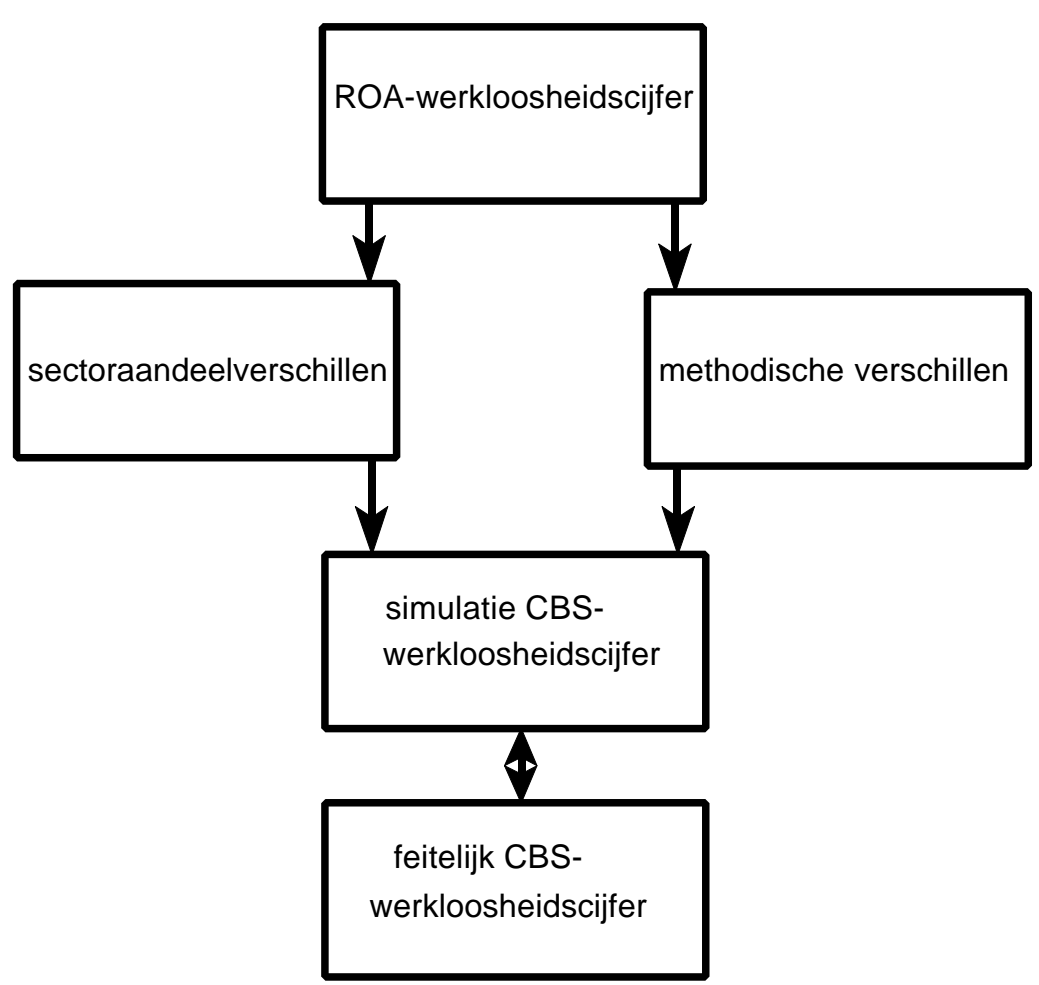

$\mathrm{H}$ e $\mathrm{t}$

verschil in de gepresenteerde werkloosheidspercentages kan op twee manieren worden veroorzaakt. Enerzijds kunnen er verschillen in de onderzochte populatie zijn. Zowel het ROA als het CBS gaat uit van een steekproef van schoolverlaters. Hierdoor kan een vertekening optreden. Anderzijds zou het verschil kunnen worden verklaard door het hanteren van verschillende definities of berekeningswijzen. Beide instituten gaan echter wel

1. Zie ROA (1998). De CBS-werkloosheid onder schoolverlaters wordt onder meer gepubliceerd in Arbeidsvoorziening (1997). 
uit van dezelfde definitie van werkloosheid: werkloze beroepsbevolking. Dit betreft de mensen zonder werk (of met werk minder dan 12 uur per week) die minstens 12 uur per week willen werken, daarvoor direct beschikbaar zijn en bovendien actief zoeken naar werk, ongeacht of men bij een arbeidsbureau staat ingeschreven.

Gezien het feit dat op basis van de ROA-gegevens een simulatie kan worden gemaakt van de CBS-werkwijze, is ervoor gekozen om bij de analyse van de verschillen tussen CBS- en ROA-cijfers vanuit het ROA-werkloosheidspercentage naar het CBS-cijfer 'toe te werken'. Het onderzoek wordt daarbij beperkt tot de schoolverlaters van het HBO. De afgestudeerden van dit opleidingstype zijn in beide bronnen voldoende vertegenwoordigd ${ }^{2}$.

In figuur 1 staat weergegeven hoe te werk zal worden gegaan. Het ROA-werkloosheidspercentage wordt als vertrekpunt genomen. In de eerste plaats kunnen er, zoals gezegd, verschillen in de steekproef zijn. Er zal worden nagegaan in hoeverre CBS en ROA een afwijkende verdeling van de opleidingsrichtingen in hun gegevens hebben. Door de CBSverdeling op te leggen aan de ROA-gegevens wordt een beeld van het effect van een eventueel verschil op het werkloosheidscijfer verkregen. De tweede verklaringsgrond betreft de methodische verschillen. Het toepassen van de CBS-methodiek op de ROA-gegevens geeft inzicht in de omvang van het effect van de verschillen in methodiek op het werkloosheidspercentage.

Dit werkdocument is verder als volgt opgebouwd. Eerst wordt in paragraaf 2 een kort overzicht gegeven van de door het CBS en ROA gehanteerde databronnen. Aansluitend wordt in deze paragraaf ingegaan op de verschillen in populatie tussen beide steekproeven. Tot slot van paragraaf 2 worden de methodische verschillen tussen ROA en CBS bij het bepalen van het werkloosheidspercentage in kaart gebracht. In paragraaf 3 wordt het effect van de populatieverschillen en de methodische verschillen in kaart gebracht. Het werkdocument wordt in paragraaf 4 afgesloten met een conclusie.

2. Afgestudeerden van het WO zijn nog niet in het ROA-onderzoek opgenomen en bovendien is de steekproefomvang bij het CBS voor deze groep vrij laag. Het MBO is zeer divers. Bij het CBS wordt daarbinnen geen onderscheid naar niveau of leerweg gemaakt, terwijl bij het ROA niet alle vormen van MBO in het onderzoek zijn opgenomen. Schoolverlaters van het voortgezet onderwijs stromen met name door naar vervolgonderwijs en bieden zich derhalve niet aan op de arbeidsmarkt. 


\section{Verschillen in enquête-opzet}

\section{Gehanteerde databronnen en afbakening populatie schoolverlaters}

Het CBS baseert de werkloosheid onder schoolverlaters op de Enquête Beroepsbevolking (EBB). De EBB is een maandelijks uitgevoerd steekproefonderzoek onder personen woonachtig in Nederland met uitzondering van personen in inrichtingen, instellingen en tehuizen (CBS, 1998). Het onderzoek vindt face-to-face plaats door enquêtrices die gebruik maken van schootcomputers. De jaarlijkse netto steekproef bedraagt zo'n 110.000 huishoudens. De steekproef bevat jaarlijks zo'n 2.000 schoolverlaters. De EBB is aan de ene kant gericht op het in kaart brengen van de arbeidsmarktpositie van de werkzame beroepsbevolking (bedrijf, beroep, opleiding, dienstverband, arbeidsduur e.d.) Aan de andere kant is een belangrijke doelstelling van de EBB om de statistiek over de werkloosheid in Nederland te verzorgen. Een van de mogelijkheden die de EBB biedt, is de bepaling van het werkloosheidspercentage onder schoolverlaters. De definitie van schoolverlater die het CBS daarbij hanteert is als volgt: een persoon die tussen de 15 en 34 jaar oud is, wiens laatst gevolgde opleiding een voltijd opleiding was, die nu geen student meer is of dat wel is maar dan bezig is met een deeltijd opleiding of een korte opleiding (minder dan 6 maanden) en die in de enquête aangeeft twaalf maanden geleden een voltijd opleiding te hebben gevolgd.

Voor de bepaling van het werkloosheidspercentage onder afgestudeerden van het HBO maakt het ROA gebruik van de HBO-monitor. Dit is een grootschalige schriftelijke enquête onder afgestudeerden van het HBO. De enquête vindt jaarlijks in het najaar plaats onder de afgestudeerden die gemiddeld zo'n anderhalf jaar eerder de opleiding met diploma hebben verlaten. Deelname van HBO-instellingen aan de HBO-monitor gebeurt op basis van vrijwilligheid. Aangezien echter een grote meerderheid van de hogescholen participeert in de HBO-monitor mag worden aangenomen dat deze een representatief beeld geeft. De netto steekproef bedraagt zo'n 15.000 afgestudeerden. Bovendien worden de gegevens op gedetailleerd niveau van opleidingen en naar regio en geslacht gewogen naar de werkelijke landelijke populatie.

De HBO-monitor beoogt primair een inzicht te verkrijgen in het arbeidsmarktintredeproces van afgestudeerden. Daarbij is ervoor gezorgd dat vragenlijst, definities, classificaties e.d. zijn afgestemd op die van de EBB. Voor de analyses in dit werkdocument gaan we uit van de HBO-monitor 1996 (zie Van de Loo, Van der Velden en Zuurbier, 1997). Dit betreft de afgestudeerden $^{3}$ van het studiejaar 1994/1995. Afgestudeerden die in een voltijdse opleiding gaan verder leren worden - vergelijkbaar met de CBS-gegevens - bij de bepaling van het werkloosheidspercentage buiten beschouwing gelaten.

3. De HBO-monitor meet zowel de afgestudeerden van het voltijd als het deeltijd onderwijs. Voor deze analyse is een selectie gemaakt op de afgestudeerden van de voltijdse opleidingen. 
In tegenstelling tot de EBB worden door het ROA de afgestudeerden uit een bepaald studiejaar op één moment geënquêteerd. Afhankelijk van de afstudeerdatum betekent dit dat op moment van enquête de HBO'ers minimaal 14 maanden en maximaal 26 maanden geleden zijn afgestudeerd. Tabel 1 geeft hiervan een overzicht. Het blijkt dat het overgrote deel van de HBO-studenten in de maanden juni en juli afstudeert ${ }^{4}$. Het grootste deel van de HBO'ers wordt derhalve ongeveer 16 maanden na afstuderen geënquêteerd.

Tabel 1

Afstudeermaand van HBO'ers studiejaar 1994/1995 in relatie tot aantal maanden tussen afstuderen en enquêtemoment HBO-monitor op enquêtemoment afgestudeerden

$\begin{array}{lrr}\text { september } & 25-26 & 3,4 \\ \text { oktober } & 24-25 & 1,4 \\ \text { november } & 23-24 & 1,5 \\ \text { december } & 22-23 & 2,4 \\ \text { januari } & 21-22 & 5,1 \\ \text { februari } & 20-21 & 4,1 \\ \text { maart } & 19-20 & 1,8 \\ \text { april } & 18-19 & 1,7 \\ \text { mei } & 17-18 & 4,9 \\ \text { juni } & 16-17 & 30,5 \\ \text { juli } & 15-16 & 35,3 \\ \text { augustus } & 14-15 & 8,0\end{array}$

Bron: ROA/HBO-monitor 1996

Zoals blijkt uit de opzet van beide steekproeven, zijn de meetperioden van beide steekproeven niet gelijk. De EBB-enquête uit het jaar 1996 bevat personen die hun HBOdiploma hebben behaald in de periode januari 1995 tot en met november 1996. De HBOmonitor 1996 bevat schoolverlaters van de periode september 1994 tot augustus 1995 . Deze personen zijn vervolgens (retrospectief) geënquêteerd rond november 1996. Beide enquêtes betreffen dus niet exact dezelfde groep schoolverlaters en hebben bovendien betrekking op een iets afwijkende periode. Gelet op de algemene economische ontwikkeling en met het oog op de relatief geringe celgrootte in de EBB, wordt de HBOmonitor 1996 vergeleken met het gemiddelde van de EBB-enquêtes van de jaren 1995,

4. Deze verdeling wijkt licht af van de CBS-verdeling. De consequenties voor de verschillenanalyse zijn echter gering. Ze zullen in paragraaf 3 bij de methodische verschillen worden besproken. 
1996 en $1997^{5}$. Op basis van de HBO-Monitor stelt het ROA de werkloosheid (voor de hier afgebakende groep) op $7 \%$. Het CBS gaat uit van een werkloosheidpercentage van $17 \%$.

\section{Representativiteit van de gegevens}

De eerste vraag die kan worden gesteld is: hoe representatief zijn beide enquêtes voor de totale populatie schoolverlaters? De ROA-gegevens zijn, zoals gezegd, op gedetailleerd niveau van opleiding gewogen op basis van gegevens van het Centraal Register Opleidingen Hoger Onderwijs (CROHO). De herweging van de EBB vindt plaats voor de gehele (beroeps)bevolking door gebruikmaking van onder meer bestaande registraties (bv. regio, leeftijd). In tabel 2 wordt voor beide enquêtes een overzicht gegeven van de verdeling van de HBO-afgestudeerden over zeven opleidingsrichtingen. Deze indeling is gebaseerd op de Standaard Onderwijs Indeling (SOI) van het CBS (zie ook de hoofdcategorieën die zijn afgebakend in ROA, 1997). Opgemerkt wordt dat deze indeling afwijkt van de HBOMonitorindeling, welke is afgestemd op de in het onderwijsveld gehanteerde afbakening.

Het blijkt dat de verdelingen over opleidingsrichtingen redelijk overeenkomen. Slechts wat betreft de opleidingsrichtingen HBO onderwijs en tolk en vertaler en HBO economie zijn er grotere verschillen tussen beide enquêtes te constateren. De eerstgenoemde opleidingsrichting heeft een groter aandeel in de ROA-gegevens, terwijl de laatste opleidingsrichting juist een groter aandeel in de CBS-gegevens heeft.

Tabel 2

Aandeel HBO-afgestudeerden naar opleidingsrichting (gewogen cijfers)

$\begin{array}{lccc}\text { Opleidingsrichting } & \mathrm{ROA} & \mathrm{CBS} & \text { verschil } \\ \% & & \%\end{array}$

$\begin{array}{lrrr}\text { HBO onderwijs en tolk en vertaler } & 19,0 & 15,9 & 3,1 \\ \text { HBO landbouw } & 4,0 & 3,9 & 0,1 \\ \text { HBO techniek } & 23,1 & 21,3 & 1,8 \\ \text { HBO paramedisch } & 9,3 & 9,4 & 0,1 \\ \text { HBO economie } & 26,7 & 31,8 & -5,1 \\ \text { HBO sociaal-cultureel } & 12,9 & 13,6 & -0,7 \\ \text { HBO kunst } & 5,0 & 4,1 & 0,9 \\ & & & \\ \text { Totaal } & 100 & 100 & \end{array}$

5. De EBB-enquêtes van 1995, 1996 en 1997 bevatten afgestudeerden van de periode februari 1994 tot en met november 1997. De HBO-monitor 1996 geeft informatie over afgestudeerden vanaf het afstudeermoment (vanaf september 1994) tot het moment van enquête (eind 1996). De perioden februari 1994 tot en met augustus 1994 en november 1996 tot en met november 1997 zitten dus wel in de EBB-enquêtes maar niet in de HBO-monitor 1996. Gezien de ongeveer gelijke grootte van deze perioden en het verloop van de werkloosheid (hoger dan gemiddeld in de eerste periode en lager dan gemiddeld in de tweede periode kunnen beide perioden waarschijnlijk tegen elkaar uitgevlakt worden zonder dat het ernstige consequenties heeft voor het gemiddelde werkloosheidspercentage over de driejarige periode. 
Bron: ROA/HBO-monitor 1996, CBS/EBB 1995-1997

\section{Gebruikte methodieken}

De tweede vraag die kan worden gesteld is in hoeverre de methodische verschillen tussen het ROA en het CBS van invloed zijn op het gepresenteerde werkloosheidspercentage? Door gebruikmaking van de maandelijkse EBB-gegevens beschikt het CBS over twaalf meetmomenten per jaar. Deze twaalf meetmomenten leveren twaalf maandelijkse werkloosheidspercentages onder schoolverlaters op. Vervolgens neemt het CBS het gemiddelde van twaalf op één volgende maandelijkse werkloosheidspercentages om zodoende een jaarcijfer te genereren. Het is dit jaargemiddelde dat wordt gepresenteerd. Het ROA meet, zoals gezegd, de afgestudeerden op één moment, namelijk zo'n anderhalf jaar na afstuderen. Het op dit tijdstip verkregen werkloosheidspercentage is het door het ROA gepresenteerde werkloosheidspercentage.

\section{Analyse van de verschillen}

\section{Populatieverschillen}

Zoals de vorige paragraaf heeft laten zien, is het verschil in de verdeling over de opleidingsrichtingen tussen beide enquêtes beperkt. Het effect van deze afwijkende verdeling op het

Tabel 3

Werkloosheidspercentage onder schoolverlaters van de zeven opleidingstypen in het HBO

Opleidingsrichting

werkloosheid

ROA-populatie

$\%$

$\begin{array}{lr}\text { HBO onderwijs en tolk en vertaler } & 9,3 \\ \text { HBO landbouw } & 9,7 \\ \text { HBO techniek } & 5,9 \\ \text { HBO paramedisch } & 6,2 \\ \text { HBO economie } & 3,8 \\ \text { HBO sociaal-cultureel } & 7,2 \\ \text { HBO kunst } & 19,2 \\ \text { Totaal met populatieverdeling ROA } & 7,0 \\ \text { Totaal met gesimuleerde populatieverdeling CBS } & 6,7\end{array}$


werkloosheidspercentage is dan ook gering. Tabel 3 geeft de werkloosheid onder school verlaters per richting op basis van de HBO-monitor ${ }^{6}$. Wanneer vervolgens de herweging van de populatieverdeling wordt gemaakt naar de verdeling zoals die bij de EBB geldt, levert dit - bij gebruikmaking van de werkloosheid per opleidingsrichting volgens de ROA-gegevens - een verschil in werkloosheid op van 0,3\%-punt.

\section{Methodische verschillen}

De uitgebreide vragenlijst die voorgelegd is aan de deelnemers aan de HBO-monitor biedt de mogelijkheid om de in de vorige paragraaf beschreven methodiek van het CBS te simuleren. In de HBO-monitor-vragenlijst is namelijk een 'kalender' opgenomen waarop de afgestudeerden per maand kunnen aangeven wat hun maatschappelijke positie was vanaf het moment van afstuderen tot aan het moment van enquête. Op basis van deze informatie is het mogelijk om een schatting te maken van het werkloosheidspercentage onder schoolverlaters gedurende de eerste anderhalf jaar na afstuderen. Hierbij dient te worden opgemerkt dat het hier een subjectieve werkloosheidsmaatstaf betreft, die niet getoetst is op basis van de voor de definitie van werkloze beroepsbevolking geldende criteria. In dit geval geven respondenten zelf aan hoe zij tegen hun positie aankijken. Aangezien echter ook de maatschappelijke positie voor het enquêtemoment - het moment waarop het ROA het officiële werkloosheidspercentage op basis van de geldende criteria vaststelt - bekend is, kan het verschil tussen beide maatstaven worden bepaald. Het blijkt dat afgestudeerden subjectief gezien hun arbeidsmarktpositie minder vaak als werkloos beschouwen. Terwijl het officiële werkloosheidspercentage voor HBO'ers 7,0\% bedraagt, beschouwt slechts $5,5 \%$ van de respondenten die zich aanbieden op de arbeidsmarkt zichzelf als werkloos. Het verschil is een factor 1,26 . Als vervolgens wordt aangenomen dat deze factor voor de gehele periode gelijk is, dan kan het, wat kan worden aangeduid als het geobjectiveerde werkloosheidspercentage worden berekend. Dit is weergegeven in figuur 2 .

Figuur 2

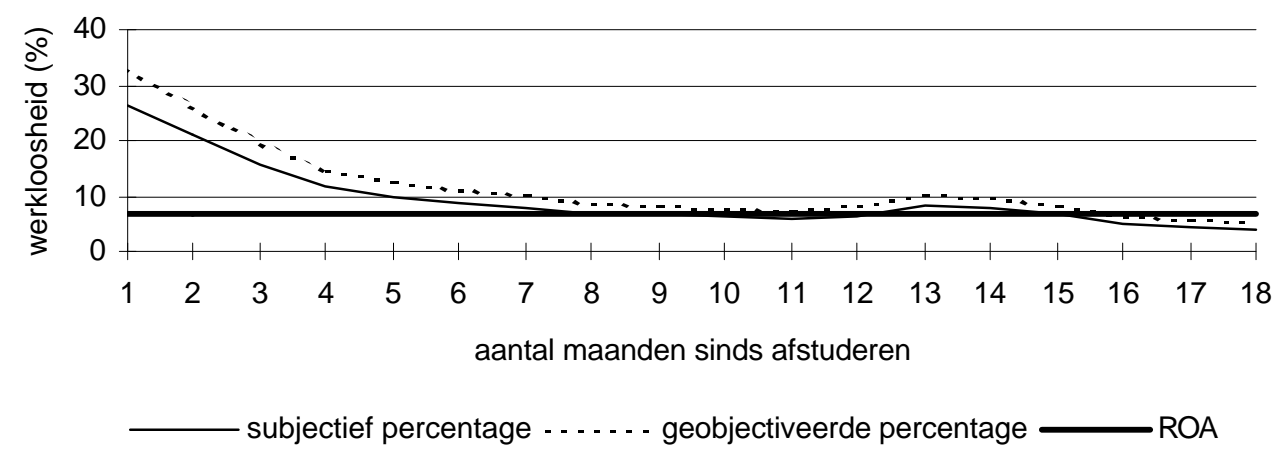

D e intredewerklo osheid van schoolverlate rs gebaseerd op gegevens van de HBOmonitor

6. Hierbij wordt de kanttekening gemaakt dat in dit werkdocument, in navolging van het CBS, alleen afgestudeerden zijn meegenomen in de leeftijdsklasse 15-35 jaar. In de reguliere ROApublicaties is er geen leeftijdsbeperking. De effecten van deze leeftijdsbeperking op het werkloosheidspercentage zijn voor het $\mathrm{HBO}$ echter verwaarloosbaar klein. 
In de figuur staat het werkloosheidspercentage van HBO'ers in de eerste 18 maanden na afstuderen weergegeven. De doorgetrokken lijn geeft de gegevens weer die uit de kalender naar voren komen. De stippellijn geeft de geobjectiveerde werkloosheid aan onder de afgestudeerden. De dikke lijn geeft het door het ROA gepresenteerde werkloosheidscijfer op het enquêtemoment weer. Het blijkt dat in de eerste maand na afstuderen ongeveer een derde van alle HBO'ers werkloos is. Na verloop van tijd daalt dit percentage.

Naast deze werkloosheidscijfers beschikt het ROA ook over de officiële afstudeermaand van de afgestudeerde (zie tabel 1). Een combinatie van de werkloosheid en de afstudeermaand stelt ons in staat om de twaalf meetmomenten van het CBS te simuleren. Immers wanneer een persoon afstudeert in bijvoorbeeld januari dan is bij benadering bekend hoe groot de kans is dat hij werkloos is in februari (werkloosheidspercentage na één maand), in maart (werkloosheidspercentage na twee maanden) enz. Een aggregatie van alle afgestudeerden levert dan voor elke maand een werkloosheidspercentage op. Wanneer nu het gemiddelde wordt genomen van de twaalf maandelijkse werkloosheidspercentages is de CBS-methodiek gesimuleerd. Figuur 3 geeft de maandelijkse werkloosheidspercentages weer, die gemaakt zijn op basis van de ROA-gegevens. De piek in de maand augustus is te verklaren uit het feit dat juist in de maanden juni en juli het merendeel van de HBO'ers afstudeert. De stippellijn geeft nu het gemiddelde van deze twaalf maanden weer. Dit gemiddelde bedraagt 13,9\%.

Figuur 3

Simulatie van het werkloosheidspercentage van het CBS op basis van ROA-gegevens

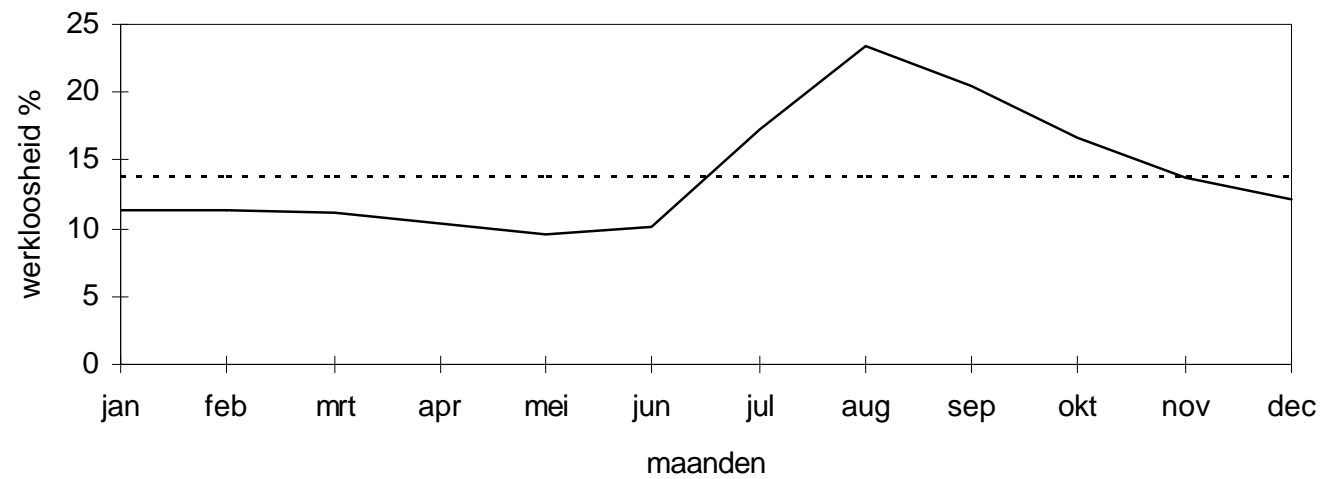


Het blijkt derhalve dat deze methodische verschillen tussen het CBS en het ROA 6,9\%-punt $(13,9-7,0)$ kunnen verklaren van het verschil tussen het door het CBS en het door het ROA gepresenteerde werkloosheidspercentage. Wanneer ook de effecten van de verschillen in representativiteit van de gegevens tussen het CBS en het ROA worden meegenomen, blijkt dat beide effecten te zamen kunnen verklaren dat het CBS-percentage 6,3\%-punt hoger ligt dan het ROA-percentage. In de praktijk ligt het CBS-percentage 10\%punt hoger. Er resteert dus nog een verschil van 3,7\%-punt.

Een mogelijke reden voor dit nog onverklaarde verschil zouden geheugeneffecten kunnen zijn. Zoals eerder vermeld, wordt in de HBO-monitor gebruik gemaakt van een kalender om de maatschappelijke positie van de afgestudeerden in het eerste jaar na afstuderen te bepalen. Deze kalender is door de afgestudeerde ingevuld op het moment van enquête, dat wil zeggen, zo'n anderhalf jaar na afstuderen. De afgestudeerden moeten dus in hun geheugen teruggaan om te achterhalen wat hun maatschappelijke positie in de tussenliggende periode was. Het is mogelijk dat de betrouwbaarheid van de op basis van de kalender van de gegevens afneemt naarmate het tijdstip in de kalender verder terug in de tijd is gelegen. In de EBB-enquête speelt dit probleem niet.

Door gebruik te maken van het verloop van de (objectieve) werkloosheidspercentages van het CBS over de periode na afstuderen kan worden nagegaan of het resterende verschil inderdaad aan geheugeneffecten kan worden toegeschreven. Dit is weergegeven in figuur 4. In deze figuur staat het objectief bepaalde CBS-werkloosheidspercentage van HBOafgestudeerden in de eerste twaalf maanden na afstuderen (stippellijn) en het geobjectiveerde ROA-percentage (dunne doorgetrokken lijn; zie figuur 2). Aangezien het CBS-percentage geen stabiele reeks vormt, is een onderliggende logaritmische functie geschat. Deze is in figuur 4 weergegeven met de dikke lijn. De vergelijking van de geobjectiveerde ROA-werkloosheidsontwikkeling met de geschatte CBSwerkloosheidscurve bevestigt dat er inderdaad sprake is van geheugeneffecten in de ROAcijfers. Vlak na afstuderen is er een aanzienlijk verschil tussen beide cijfers. Naarmate het aantal maanden sinds afstuderen toeneemt, met andere woorden naarmate we dichter bij het enquêtemoment komen, wordt het verschil kleiner. In de buurt van het enquêtemoment is het verschil tussen beide cijfers zelfs nihil. Dit wijst er op dat het nog resterende onverklaarde verschil grotendeels is toe te schrijven aan de geheugeneffecten.

Figuur 4

Geheugeneffecten in de ROA-data 


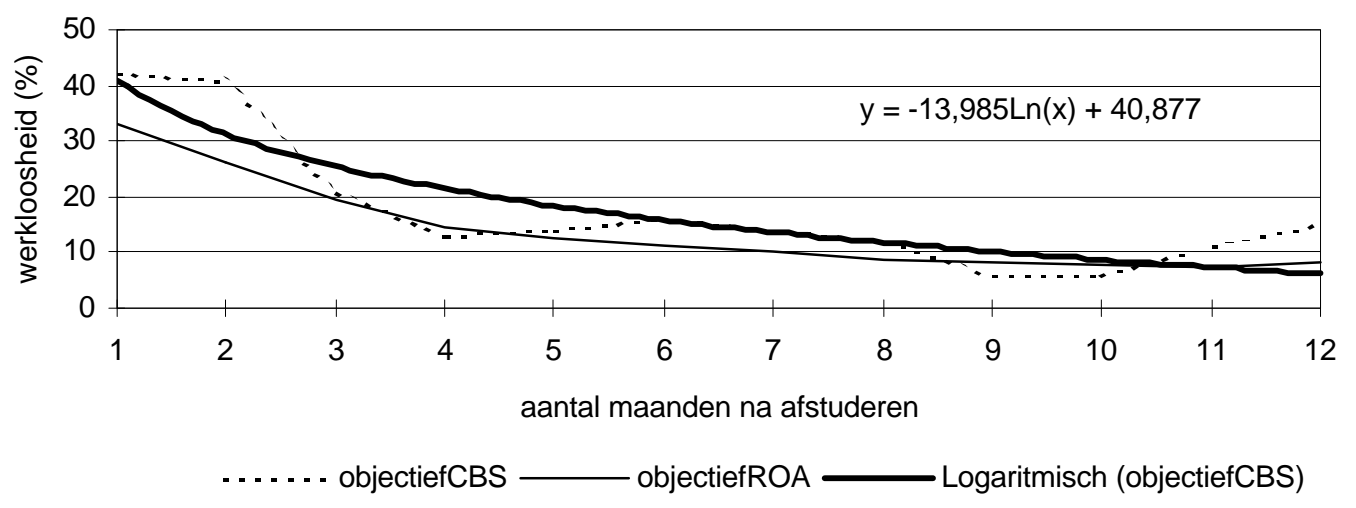

\section{Conclusie}

In dit werkdocument is het verschil in door ROA en CBS gepresenteerde werkloosheidscijfers onder schoolverlaters verklaard. Voor HBO'ers blijkt er een verschil te zijn van maar liefst 10\%-punten: CBS 17\% en ROA 7\%. Daarbij zijn op basis van de ROA-gegevens de CBS-cijfers gesimuleerd.

Een eerste verschilpunt betreft de representativiteit van de gegevens. Wanneer op basis van de door de geconstateerde werkloosheidspercentages per sector een simulatie van de CBS-cijfers wordt gemaakt, bedraagt de werkloosheid $6,7 \%$; een gering verschil van $0,3 \%$ punten, dat echter de discrepantie tussen ROA- en CBS-cijfers alleen maar groter maakt. Een tweede factor blijkt belangrijker. Dit betreft een verschil in methodiek die samenhangt met het tijdstip van dataverzameling: bij CBS verdeeld over de eerste 12 maanden na afstuderen en bij ROA gemiddeld 16 maanden na afstuderen. Het effect van dit verschil is $6,9 \%$-punten. Beide factoren kunnen derhalve niet het gehele verschil tussen beide werkloosheidscijfers verklaren. Een resterend verschil van 3,7\%-punten is grotendeels het gevolg van geheugeneffecten. Voor het uitvoeren van de reconstructie is gebruik gemaakt van retrospectieve informatie in de HBO-monitor. Bij gebruik van retrospectieve vragen mag worden verwacht dat respondenten bepaalde gebeurtenissen vergeten te rapporteren. Overigens wordt expliciet opgemerkt dat voor het bepalen van werkloosheidspercentages door het ROA geen gebruik wordt gemaakt van retrospectieve gegevens.

Uit de uitgevoerde analyse kan een tweetal belangrijke conclusies worden getrokken. De eerste betreft de interpretatie van de CBS-cijfers. Deze geven niet het werkloosheidspercentage op een bepaald moment aan, maar weerspiegelen de ontwikkeling van de werkloosheid onder schoolverlaters in de eerste twaalf maanden na afstuderen. Gemiddeld genomen wordt een schoolverlater in de EBB na 6 maanden geënquêteerd. De 
ontwikkeling van de werkloosheid in het eerste jaar na afstuderen is echter geen lineair proces. Figuur 5 licht dit toe. De stippellijn geeft de ontwikkeling van het werkloosheidspercentage na afstuderen aan (dit is de dikke lijn in figuur 4). De rechte lijn in figuur 5 geeft het gemiddeld werkloosheidspercentage volgens het CBS weer. Op grond van de figuur kan worden afgelezen dat het CBS-werkloosheidspercentage overeenkomt met de werkloosheid iets meer dan 5 maanden na afstuderen ${ }^{7}$. Dit verklaart - naast het genoemde kleine populatie-effect - het verschil met de ROA-cijfers. Deze laatste hebben immers betrekking op de situatie zo'n 16 maanden na afstuderen. Dan is de werkloosheid aanzienlijk lager.

7. Deze termijn geldt voor de hier geanalyseerde dataset. Voor andere jaren kan deze periode anders zijn. Het CBS-werkloosheidspercentage geeft in feite een indicatie van de duur en de omvang van de werkloosheid. 
Figuur 5

Resultaten van beide methodieken voor de berekening van het werkloosheidspercentage

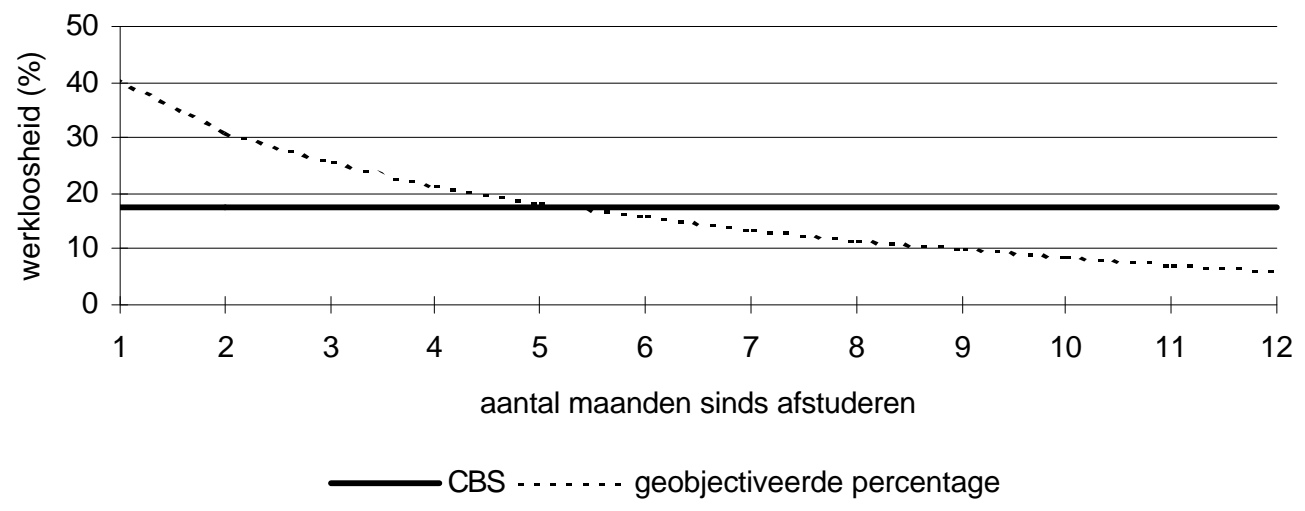

De tweede belangrijke conclusie heeft geen betrekking op het werkloosheidspercentage, maar op de duur van de intredewerkloosheid die door het ROA wordt gerapporteerd (zie bijvoorbeeld ROA, 1998). Niet alleen is hierbij sprake van een verschil in definitie intredewerkloosheid heeft betrekking op de subjectieve maatschappelijke positie van schoolverlaters in de intredeperiode - maar bovendien blijken geheugeneffecten een rol te spelen. Beide effecten impliceren dat de intredewerkloosheid door het ROA enigszins wordt onderschat.

\section{Literatuur}

Arbeidsvoorziening (1997), Schoolverlatersbrief 1997, Zoetermeer.

CBS (1998), Enquête Beroepsbevolking 1997, Voorburg/Heerlen.

Loo, P.J.E. van de, R.K.W. van der Velden, H.M. Zuurbier (1997), De arbeidsmarktpositie van afgestudeerden van het hoger beroepsonderwijs HBO-Monitor 1996, Voorlichtingsdienst HBORaad, Den Haag.

ROA (1997), De arbeidsmarkt naar opleiding en beroep tot 2002, ROA-R-1997/7, Maastricht.

ROA (1998), Schoolverlaters tussen onderwijs en arbeidsmarkt 1997, ROA-R-1998/5, Maastricht. 